\title{
The Gauls Warfare Depiction in Art during the Hellenistic Era \& Their Influence on Founding Today's France
}

\author{
Heba Farid \\ PhD holder, Greco-Roman Archaeology, Faculty of Arts, \\ Alexandria University, Egypt \\ hebafarid2@yahoo.com/h.farid@alexu.edu.eg
}

\begin{abstract}
The article analyses the reflection of Attalus' important victories over the Galatians in Art till the last king of Pergamon, Attalus III, left his kingdom to Rome in 133 B.C and the influence the contemporary art pieces depicting these wars on religion and politics. Most scientific papers and specialized textbooks have limited the examination of those pieces exclusively to their aesthetic influence regarding the feelings and emotions the statues portray or as historical records of Atallus' war victories during the Hellenistic period. None of them have examined the political and historical consequences resulting from the creation of these artifacts across a prolonged timeline; from the Hellenistic period and passing through the Roman era up till today, away from their original purpose, and towards quite different ones that occurred due their creation and perception.
\end{abstract}

Keywords: Hellenism, The Pergamon Frieze, Gaul, Attalus I, Archaeological Original Greek Mythology, Gods and Giants, Small Gallic Group, Interpretation, Installation.

$$
\begin{aligned}
& \text { تصوير حرب الإغريق في الفن خلال العصر الهيليني وتأثيرها على تأسيس فرنسا اليوم } \\
& \text { هبة فريد } \\
& \text { كلية الآداب، الآثار اليونانية الرومانية، جامعة الإسكندرية، مصر } \\
& \text { hebafarid2@yahoo.com/h.farid@alexu.edu.eg } \\
& \text { الملخص: يحلل هذا المقال آثنار انتصارات أتالوس على الغاليين في الفن وصولا إلى توريث برجامة للرومان، } \\
& \text { ومدى تأثير تلك القطع الفنية في إعادة صياغة التاريخ عقب العصر اللِّلِّنستى وصولاً للعصر الحديث، فكان لها لهان } \\
& \text { كبير الأثر في كتابة التاريخ الحديث ونشأة بلد قوية كفرنسا. } \\
& \text { اقتصرت معظم الكتب العلمية والدراسات البحثية على دراسة تلك الاعمال الفنية من الجانب الفني فقط دون }
\end{aligned}
$$

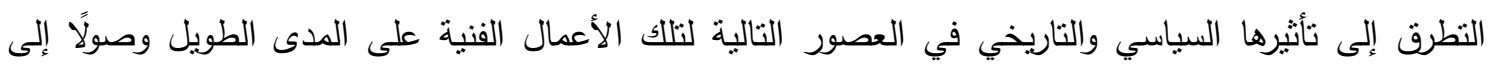

$$
\begin{aligned}
& \text { العصر الحديث. وتغيَر الهدف الأساسي الذي أُنشأت من أجله، والذي ساهم بدوره في تغير الفكر والنظرة الموجهة }
\end{aligned}
$$

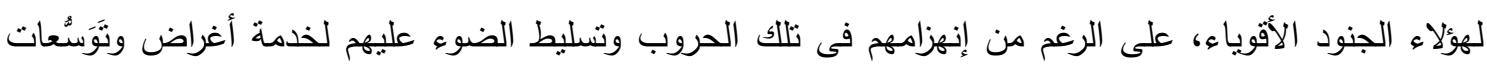

$$
\begin{aligned}
& \text { سياسية أخرى. } \\
& \text { الكلمات الدالة: أتالوس الأول، الغاليين، برجامة، الدعاية السياسية، الأساطير اليونانية، حروب الغال، فرنسا، }
\end{aligned}
$$




\section{Introduction: The History of the Gauls Statues.}

Naturally, the region of Pergamon played an important role in the development of different arts because Pergamon was a melting pot of multi-racial/cultural population and groups belonging to different regions of the ancient world. The Pergamon site has made it a meeting place for different civilizations and cultures in the Mediterranean Sea as well as the Aegean Sea. Artistic production did not stop at its borders due to the continuous maritime trade; carrying its artistic trends from one place to another.

Art has ceased to evolve since the fifth century, as a result of the Persian invasion and the migration of artists to Greece, which prevented the great development of Greek art at Pergamon in the Classical era until the arrival of the King of Macedonia, "Alexander, the Great" in Asia during the Autumn of 334 B.C, when Pergamon became the most influential Hellenistic city under the Attalid Dynasty from 282 till 133 B.C. And since the time of Philetaerus, the uncle of Eumenes I and the first Attalid ruler, the city of Pergamon had begun to flourish and develop during the Hellenistic Age till it started to compete with Athens School of Arts, and started to write its own history.

Pergamon, and indeed all of Asia Minor and Athena, suffered from a number of problems caused by the Gauls, one of which was exacting tributes to avoid war or other repercussions. Eumenes I had, along with other rulers, dealt with the Galatians by paying tributes. However, the domination of the Gauls was stopped later when Attalus refused to pay them, becoming the first such ruler to do so. As a consequence, the Gauls planned to attack Pergamon. Attalus met them near the sources of the river Caicus and gained a victory that drove the Gauls away from this region. ${ }^{1}$

Following the victory of Attalus, he took the name of Soter, which means "savior", and got the title of "King". The victory brought Attalus legendary fame because of this title that had not been used since the fifth century. Not only was the victory over the Gauls important for Pergamon and its borders, but it was also a message to the whole world; a proof of Pergamon's power, then Pergamon turned into a city that would rival the golden age of Athens in all different artistic and cultural sciences. ${ }^{2}$

Years after the first victory over the Gauls, Pergamon, along with its ally, Antiochus, the ruler of Seleucid Asia Minor, were targeted by the Gauls again. This time, Attalus crushed them; both the Gauls and Antiochus, at the battle of Aphrodisum and again at a second battle in the east. As a result of these victories, Attalus obtained domination over most of Asia Minor. ${ }^{3}$

Pergamon was at its height during the Hellenistic Age and rose to build monuments to showcase the power and wealth achieved from the victories against the Gauls, especially the one by Attalus I, because the art of sculpture, in general, reflects the spiritual and cultural development of the artists of his time. So a work of art tries to

\footnotetext{
${ }^{1}$ Jerome Jordan Pollitt, Art in the Hellenistic Age (Cambridge University press, 1986), 81.

${ }^{2}$ Renee Dreyfus and Ellen Schraudolph, Pergamon: The Telephos Frieze from the Great Altar (Arts Museums of San Francisco press, 1996), 11-13.

${ }^{3}$ Marten Van Nieuwkoop, The Galatian Suicide "Unravelling The Ludovisi Gaul Killing Himself And His Wife” (Laiden: Faculty of Archaeoogy Press at Leiden University, 2012), 360.
} 
embody the conditions and components of the era and what it has reached. This is evident when Attalus fulfilled one of his objectives by constructing monuments atop the Acropolis at Pergamon, which developed a new school of sculpture to be used for political propaganda, these included The Great Altar and The Dying Gauls. ${ }^{1}$

The Great Altar is the most outstanding monument of Gaul's history, not only in Asia Minor, but throughout the Greco-Roman world as a whole. Its creation resembled what happened in the ancient city of Athena when it defeated the Persians and showcased this defeat through the construction on the Acropolis and the Parthenon. The Acropolis of Pergamon is located on a hill $335 \mathrm{~m}$ high, which was constructed similar to the Acropolis of Athens, so that the Acropolis of Pergamon becomes the centre for spreading civilization to the whole world. It did not only develop artistic thought, but it also developed all scientific and intellectual aspects of their connection with each other; as art served politics and politics contributed to religion, and economy affected art and politics. Therefore, any development in any aspect contributed to the advancement of all other aspects of life. ${ }^{2}$

Cities, like Pergamon and Athena, had a strong motive behind constructing monuments and it was the desire to demonstrate their power and wealth to citizens, visitors, and the world, as well as to memorialize the defeat of a notable enemy. In these works, the Gauls were transformed into Giants, which means that the historical was turned into mythological, so as to celebrate the universal dimension of Pergamon's victory over them to save the world. They were perceived as global enemies and a threat to universal security because they had been troubling the Greco-Roman world for centuries. $^{3}$

Apparently, the idea of heroism has been changed as it depicted the enemy's physical strength and courage during battle and their struggle to resist defeat to reflect the strength of the victor as he is an opponent whose victory deserves to be immortalized for his courage and strength. In this sense, Attalus wanted to say that his army had defeated the capable Gallic soldiers. He wanted to show his people, the Athenians, what his soldiers suffered while wrestling with the brutal Gauls, those giants with their muscles and impregnable bodies. Therefore, the sculptural groups were all created in a baroque style to deliver Attalus' message. He also wanted the pieces to portray the acts of war. Hence, in the war of Pergamon against the Gauls, the Greeks are portrayed fighting against the barbarian Persians, as if they are Olympian gods fighting a war against giants. $^{4}$

Obviously, The Great Altar represents the center of the religious power, and it also shows how universal and elemental forces of night and day, and sea and land, are all fighting against the evil "Giants", and how this city is emerging out of this fight as a

\footnotetext{
${ }^{1}$ Alix Kent, Meetings with the East: Athens and Pergamum (Canada: Pseudo-Dionysius, Vol17, 2015), $42-43$.

${ }^{2}$ B.F. Cook, The Elgin Marbles (Cambridge: Harvard University Press, 1984), 8.

${ }^{3}$ Pausanias, Mythology and Monuments of Ancient Athens, trans. by Jane E. Harrison (Greece: Macmillan press, 1890), 475.

${ }^{4}$ Andrew Stewart and Manolēs Korres, Attalus, Athens and the Akropolis: the Pergamene 'Little Barbarians' and their Roman and Renaissance legacy (Cambridge University Press, 2004), 84.
} 
beacon of civilization. All of these are figures of imagination of the Roman ideology, however, they were picked up after that when Attalus repelled against the chaos of the barbarians, who were this time the Gauls. ${ }^{1}$

Physical and visual representations of power were very important. Monuments became meaningful in the culture of both religious and political contexts. Although we are talking about The Great Altar from the Hellenistic age, it can be predicted that they played a prominent role within the scope of the Roman period and then within the history of Gaul, especially during Caesar's rule, and they influenced the history of Europe to become the continent we know now. ${ }^{2}$

Eventually, vision incited communication, which, in turn, inspired and created language. This contextualization is a core of the creation of the Great Altar of Zeus as it is a Gauls' visual communication piece, created to reflect the strength of the Gauls and the suffering of the war against them, expressed by the beautiful white marble sculptures.

The features of the main Frieze of the Pergamon Altar represent precisely how wild an offence against the universal order it is to blur the boundary between civilisation and barbarians and create chaos. This blurring of boundaries and mess up of the social arrangement of the city and civilisation is the offence of the Giants and the reason why they needed to be punished by the divine.

The Gauls have something in common with the ancient Giants who rose against Olympic, Greek, and Roman rules. Attalids operated on a global scale, and they united the Greco-Roman world not only by creating a common fear from them (the Gauls), but also by expressing gratitude and favour for any victory over them. Therefore, there is no doubt that this arrangement of the barbarians was created by a political mind. ${ }^{3}$

King Attalus, having conquered the Gauls (the French) in the Battle of Tolistoagii around the springs of the river Caicus, set up these statues as a gratitude offering to Athena. But the question raised here was: did he really want to thank the gods or perpetuate his victories? Or were these wonderful works created for religious or political purposes or not?

The paper at hand aims at proving the power of Pergamon and its political and cultural influences in an attempt to make it a new cultural center as powerful and politically significant as Athens was itself. This is reflected in new art forms with novel approaches of political and historical inclinations, motives and interpretations that extended not only throughout the Hellenistic era, but also to the Roman age and the modern one as well.

\footnotetext{
${ }^{1}$ James Churchill, Pergamon and the Great Altar of Zeus (NewYork: Lesa Mason press, 2015), 5-6.

2 Stewart, Attalus, Athens, and the Akropolis "the Pergamene 'Little Barbarians' and their Roman and Renaissance legacy”, 84-85.

${ }^{3}$ Kent, Meetings with the East: Athens and Pergamum, 42-43.
} 


\section{DESCRIPTION \& INTERPRETATION}

\section{Description of the Great Altar of Zeus:}

The Great Altar of Zeus derives its significance from the facts that: firstly, it is a memorial artifact that came to our days to show us how the Gauls were powerful enemies of Attalus and the Romans after them, which makes the Romans contribute to the formation and writing of the history of France, as it is known today. Secondly, the significance of the Great Altar, which was acknowledged by the ancient Romans, having ranked it among the Seven Wonders of the World, as well as the scale of this work, is actually impressive. In Pergamon, the altar's size was raised to be half of that of the Parthenon, built on the Acropolis. The relieved features of the characters in the frieze are life-sized. ${ }^{1}$

The Great Altar of Pergamon was erected around 170 B.C. by the Attalid Dynasty. It is also the monument of the dominant world order and of an ancient world war. Gigantomachy frieze, running around the podium of the altar, is a known religious story of this era and it characterizes the war between the Olympian Gods and the Giants. Its size was only matched by the Parthenon frieze, measuring over 7 feet high and more than 400 feet long. The subject matter was depicted as one large simultaneous universal event, combining the calm of the Gods with the chaos of the Giants in the quiet Classic style of the God's faces, so starkly opposed to the Giant's faces, which creates the unity of the subject as an act and a reaction as a novel that is told by a marble narrative. ${ }^{2}$

In manifold warfare scenes of supreme artistry, the gods and goddesses of this Frieze are shown in the battle against the Giants, meaning that the combat of the twelve gods in their battles against the giants was shown surrounding the Gods' followers, and they were also linked by their symbols as if they were a frame for the scene so that the viewer could identify them. The deities above fight with vitality, but in a composed manner, clearly victorious and in control. Their opponents, on the other hand, attacking from below appear in all the stages of dying as they are wounded, crushed and trampled down by the divine force to cross from above and cut the defeated Giants off. Their hair is wild, bodies are naked, some of them are depicted with nasty snake legs, and rage and frustration show in their faces, lacking restraint and all the other features which distinguish them from their "civilized" conquerors.

The legend continues in a magnificent way on the Altar of Zeus on the following friezes, from the northern frieze to the western frieze:

First, the northern frieze: has the Capitoline trinity of Zeus, Hera, and Athena at the centre, close to them are Nike as a victor, Hercules half-divine, Ares and Aphrodite as the ancestors of the Julio-Claudian dynasty, as well as Apollo as Augustus' divine father and supporter. ${ }^{3}$

The first to be carved on the northern frieze is the goddess Aphrodite, the goddess of love, who wears the chiton and rests on her right foot to raise her left foot and press her

\footnotetext{
${ }^{1}$ Russel J. Barrnett, The Pergamon Altar (France: Publishing house, 2012), 64.

2 Penelope Davies and Walter Denny, History of Art: The Western tradition (London:Laurence King Publishing, 2016), 159.

${ }^{3}$ Peter Green, Hellenistic History and Culture (Cambridge University Press, 1993), 86-87.
} 
hand on the face of one of the giants while she bows to pull her sword from the chest of this giant after killing him. To express how powerful the goddess was, the sculptor chose not the moment she stabbed him, but the moment she pulled her sword after killing him effortlessly to demonstrate strength. Standing in front of her is the god Eros, followed by a winged giant with snake legs fought by the goddess Dione, the mother of the goddess Aphrodite, who was also attacked by the goddess Eros, son of the goddess Aphrodite. They are followed by the god of war, Ares, the husband of the goddess Aphrodite.

Behind them is the goddess Nyx, the goddess of the night, one of the goddesses of darkness and revenge, holding a vase surrounded by snakes that wrap around it, and she is involved in throwing this vase at the kneeling giant in front of her.

This is followed by the goddess of fate, Moirai, and the goddess of revenge and darkness, Erinyes, who is often carved accompanying the goddess Nyx, followed by the sculpture of the goddess Keto, the goddess of lions and animals, the lion standing beside her devoured the arm of her opponent, depicting his arm, which is between the lion's teeth, and next to him stands Poseidon.

Second, the eastern frieze: on the frieze, Zeus fighting against a giant, is apparently high on a powerful horse, pushing down the crushed giant; and this is a strong symbol of imperial colonization.

It can be seen here how Gaia offers a fruit pleadingly in her left hand, asking mercy for her son, Alkyoneus, to save his life. Next, Athena is being crowned victorious by Nike. Next to the goddess Artemis, her mother, Leto, appears, who is the mother of the twins: Artemis and Apollo. Therefore, her position came in the frieze in the middle between them. Diagonals pervade the scene with rapid battle motions, while facial expressions and rugged tone represent the relaxed Olympians and the confusion of the Giants. With Athena and Gaia, these two most powerful women, culture and nature would be finally reconciled. ${ }^{1}$

In contrast to the Classical Age, the Hellenistic Age of art is widely diverse in formal, characteristic and psychological representations, which is accomplished realistically. Diversity is the main characteristic of Hellenistic sculpture. Due to a heightened interest in emotion, psychology and personification grew as vast as the influence of the new worlds opened by the Great Alexander. The baroque style, in which during the Hellenistic period the Great Altar in Pergamon was constructed, is characterized by emotional and dramatic effects, which were accomplished by mixed movements, delay, interaction, groupings and emotions. As in the Classical era, there was still an urge to show the myths of the past as a narrative. The shift in facial expression and humanizing effects, however, distinguishes the Hellenistic era from the High Classical period which concentrated more on sharing ideal beauty than reality. ${ }^{2}$

Frieze composition theatricalization appeared in a hierarchy model: there are Olympic gods at the top of the frieze and giants at the bottom. The Gods fight in an

\footnotetext{
${ }^{1}$ Fred Kleiner and Chrisitin Mamiya, Gardener's Art through the Ages (United States: Thomson Wadsworth Press, 2005), 25-30.

2 John Pedley, Greek Art and Archaeology (New Jersey: Prentice Hall Press, 2012), 354-357.
} 
ascending motion, and that of the competitor in a descending one; Hercules' figure pulling his bow, Demeter with a torch in her hands, and Hera driving a quadriga of winged horses. This depiction of the hierarchy modeled other famous reliefs of the Gigantomachy Frieze Artemis, and this was shown in the depiction of the "higher Gods" vs. "their lower enemies", as in the frieze carvings of Hercules and Clytius, Leto, Apollo and an Overthrown Giant, the Battle of Athena and Alkyoneus, and the Battle of Zeus and Porphyrion, with separate sections devoted to specific details. ${ }^{1}$

The artists were not only interested in the sequence of events, urging the link between the topic and the content, and creating a link between them in sculpture, as in the intertwined sculptural forms, but they were also interested in their private lives, by for instance depicting them next to their parents, including a husband and wife, or mother and her children, or a god and his sisters. They were not just satisfied with that, they carved their own symbols as well.

In an in-depth analysis of feelings and pathetic gestures that accompany spiritual drama, the Olympians gods of human nature fought against the power of the elements on the ground, whereas the wild gigantic nature clashed with the peaceful harmony of the world. There are energetics and expressions of movements, faces, emotions and contrasting actions. The characters of the Pergamon Frieze were interesting as they were perceived as an embodiment of contrasting contradictions, a union of emotional polarities together. Staging was also remarkable and it was evident on the frieze of the battle between the Olympic gods and the giants consisting of several stages. This is because the characteristic feature of the Zeus Altar sculpture is gods' resemblance to men.

On the Acropolis at Pergamon, great buildings were constructed to show off the power and wealth of the city. On the third one stood the Sanctuary of Athena, the city's patron goddess, complete with a temple and stoas. The temple of Athena was built in the Doric style, but with new features. For example, the columns of the peristyle are further apart and slimmer than those of the previous Doric-styled temples. This has the effect of emphasizing the military bravery of Pergamon in depicting the victories over the Gauls using the religious style. ${ }^{2}$

Linked by the opposite location of the upper side and underside, this contrast represents the location from where the giants try to attack the gods who protect humans against the lawless assault from below. Sculptures do not only record the direct visual perception for human bodies' moves and poses, but they can also interpret all of their interactions to constitute a unified system, especially in the context of the Frieze on Pergamon, as it seems to be a drama produced without sounds.

The sculptors then have entered a new phase of creating an interrelation with emotions to produce a story from real-life or a scene from a movie, to have the effect of creating a new visual attraction in a huge monumental style. They analysed the psychological feelings of their created characters. This was generally a new direction called "the phenomenon of the psychological in Arts"; an image devoid of sound which

\footnotetext{
${ }^{1}$ Simon Hornblower and Antony Spawforth, The Oxford Companion to Classical Civilization (Oxford University Press, 1998), 55-56.

${ }^{2}$ Pedley, Greek Art and Archaeology, 341-342.
} 
has a distinctive, expressive power. The entire frieze was constructed on the principle of antithesis in that there is a dramatic conflict and a structured struggle in one battle: chaos in nature in one view, harmony in the images of beautiful goddesses in another one, and the demonstration of spontaneous, animal nature by zoomorphic creatures in another. ${ }^{1}$

When carefully studying the frieze, it can be observed that there is an expansion in developing the characters of compositional groups. The dramatic plot is represented as a continuous process wherein there are accelerations; ups and downs as those found in any movie. These artists, who created the Frieze of the Great Altar, have created a single, unified image despite the fact that the frieze's authorship did not belong to one artist. $^{2}$

Unfortunately, the Pergamon Altar's fate was unfortunate. In ancient times, it was buried because of earthquakes, and despite the fact that the Frieze survived, many episodes of details were lost. While the Friezes of the Great Altar positioning were on the lower level of the temple structure at the top of the stairs, unlike the positioning of that of Athena's Temple, it was found by the German engineer Humann in 1880 in Pergamon while constructing a roadway. It was displayed in the Museum of Pergamon in 1901. After World War II broke out, it was hidden in a passage in the ground of the Berlin Zoo, then sent to Hermitage to carry out the needed restoration. The Altar had stayed in Russia till 1958, before it was taken back to Berlin. Next, it was placed in a museum constructed specially for this Pergamon Altar, where it has been demonstrated in the main exhibit up to this moment. ${ }^{3}$

The realistic and emotional representations in the small details, like the hand going upward from the rough ground, the shoes of Artemis, the wings of Nike, the face surrounded by the flowing beard, the wide and intense folds, all engraved and carved into the Pergamon Frieze, reflect the power of this composition, making it the common voice of a great tragedy resulting in a great victory. ${ }^{4}$

There can be no doubt that the Great Altar of Zeus serves more than one purpose, but the most important one is to legitimize the Pergamon Kings by the Attalid founder, and also to prove how the Gauls strength and bravery in the war make them a good ally. It was later Caesar's idea, upon reflecting on these pieces that if he had the Gauls on his side, he would become stronger, and he could win his wars.

\section{Interpreting the Gaul Sculptures from the Political Aspect:}

Two sculptures that bear witness to the potential and powerful victories for Pergamon are the sculptures of the Dying Gaul and the Ludovisi Gaul, which remain in Roman copies. Created to commemorate the victory of Attalus I over the Gauls, the two works were sculpted with realism and emotion. While they included the distinguishing features of the Gauls' race, the Gauls representations do not appear weak or servile,

\footnotetext{
${ }^{1}$ Craig Kallendorf, A Companion to the Classical Tradition (United Kingdom: John Wiley \& Sons press, 2008), 190.

${ }^{2}$ Tatiana Portnova, Giants against God's (Greece: European Research Studies, 2015), 189-196.

${ }^{3}$ Mead, The History of Herbert Treadwell Wade, 335.

${ }^{4}$ Peter Weiss and Joachim Neugroschel, A Visit to the Pergamon Altar (Berlin: Jean Stein Press, 1999), 36.
} 
instead they evoke our sympathy and admiration for their bravery. This style (Realism) was characteristic of arts created during the Hellenistic period. These monuments of the Gauls were connected to the theme of civilization defeating barbarianism, however, here, barbarianism is depicted differently. ${ }^{1}$

According to Tilley, a materialist position regards power as investing in knowledge and truth. It also clarifies the power of the Greek and Roman civilizations against lawless Gaul barbarians. It decides the Greek and Roman superiority as truth and the Greek and Roman rule as the only acceptable knowledge. Material culture refers to the representation and sense of culture. ${ }^{2}$

The Dying Gaul and The Ludovisi Gaul provide a method of historical imagination that would capture the past of the Gauls by expanding our social memory to historical events in the past associated with the history of France. ${ }^{3}$

\section{- The Interpretation of the Dying Gaul}

The Dying Gaul is a Hellenistic masterpiece of a defeated warrior; an ancient Roman marble replica of a lost bronze original made under the rules of Attalus I of Pergamon between 230 and 220 B.C to memorialize his victory over the Gauls. It has been considered a wonderful rendition of victory and defeat since that time.

The statue of the Dying Gaul depicts the artist's fiction of the realism of a wounded warrior that strives in the battle for his survival. He is known to be a Gaul by a special necklace that he is wearing during the fight, and the sword by his side and his trumpet are shaped like a horn. His body is full of strength and muscles as a warrior of his time, but his suffering is expressed obviously as he reclines on one arm. From his body language, it is also understood that he is unprepared and resists accepting death as he is fighting for his life. His stance, holding his wounds tightly, also depicts the painful suffering caused by his bleeding upper torso, reminding the viewer of the realism of the defeat of those Gauls who fought courageously nevertheless. ${ }^{4}$

It has been known from literary sources and inscriptions that the Pergammene sculptor Epigonos sculpted the original Dying Gaul bronze erected in Pergamon's Athena district. All of the Athenians, including Antigonos, a popular Greek painter of the time, watched both him and all those who helped him create this sculpture. These huge sculptures were designed to please Attalus of Pergamon's taste while also showcasing and memorialising his greatness. ${ }^{5}$

All of these monumental sculptures were part of a predominantly, ruler-sponsored propaganda effort inspired by Athens and the Greeks who liberated their empire from barbarians. The sculptors were also members of a prestigious art academy sponsored by the ruler of Pergamon.

\footnotetext{
${ }^{1}$ Esther Hansen, The Attalids of Pergamon (Cornell University Press, 1971), 305.

${ }^{2}$ Michael Shanks and Christopher Tilley, Social theory and Archaeology (Cambridge Press, 1987), 75.

${ }^{3}$ John Boardman and Murray, History of Greece and the Hellenistic World, 393-394.

${ }^{4}$ Walter Perry, Greek and Roman Sculpture (New York: Longmans Press, 1882), 559-560.

${ }^{5}$ Chris Gosden, The cultural biography of objects “World Archaeology”, 169.
} 
As a consequence, in the Dying Gaul sculpture, it was up to the sculptor to figure out how to portray a piece of victory art without the victor who is just implied. This was achieved when the victor who defeated the Dying Gaul was left out of the sculpture, allowing the viewer to imagine how much more powerful the victor is in comparison to these defeated, brave Gauls. This was supposed to be propaganda for Attalus, but it was simply and equally propaganda for the Gauls themselves as well. ${ }^{1}$

The Dying Gaul was produced throughout the ancient Mediterranean in many variants, symbolizing its importance as a triumph over lawless barbarians. As a Pergamene propaganda tool, it declared Attalid aspirations to compete with not only his Hellenistic rivals, but also the great sculptures of Pericles in Athena created during the Classical Greek rulers, in an attempt to promote Pergamene nationalism.

In this way, the sculpture of the Dying Gaul has twisted the Pergamon's historical struggles and turned them into a timeless myth, thus reordering and transforming it to be of timeless value; referring to the past of France and how brave and emotional it was, even though, during this period, its people (the Gauls/French) were considered the Barbarians in Roman eyes. ${ }^{2}$

\section{- The Interpretation of The Gaul Killing Himself and His Wife (The Ludovisi Gaul)}

This sculpture is known as the "Gaul Killing Himself and His Wife" or "The Galatian Suicide". The original statue was a feature in bronze, but, unfortunately, it has disappeared. Fortunately, the inscription on the statue bases has survived, so it is not known whether it was a Hellenistic piece of art or not. This copy appeared in the list of Ludovisi in 1623, so it is assumed that it was found in the grounds of the Villa Ludovisi in Rome a bit before that. The sculpture is now in the Palazzo Altemps, and it is a part of the National Museum of Rome. ${ }^{3}$

After the recent victories of Attalus I over the Gauls from Galatia, the Romans used it "after that time" to clarify their victory over the Gauls.

This description starts from the left with the male figure towards the right and the female figure, his wife. The material of which the statue is made of is white marble and its total height is 2.11 meters. ${ }^{4}$ It is reasonable to expect that it made quite an impression on the passing civilians of any category or religion. ${ }^{5}$

The first outstanding thing about this statue is the beautiful head of the man. His facial features, including his "eyebrows, eyes, nose, cheek, mouth, lips and chin", are in perfect Hellenistic measures, despite the fact that he is not Greek at all; he is Gaul. There are added features on the statue to specify its ethnic identity as that of a barbarian,

\footnotetext{
${ }^{1}$ Boardman, The Oxford History of Classical Art, 199.

${ }^{2}$ Brunilde Ridgway, Hellenistic Sculpture (University of Wisconsin Press, 1990), 300-301.

${ }^{3}$ Gates, Ancient Cities "The Archaeology of Urban Life in the Ancient Near East and Egypt, Greece, and Rome”, 292.

${ }^{4}$ Nigel Spivey, Greek Art (Michigan: Phaidon Press, 1997), 363.

5 Jeremy Tanner, The Invention of Art History in Ancient Greece "Religion, Society and Artistic Rationalisation"( Cambridge University Press, 2006), 226-227.
} 
not one of the Royal Greek. The most intelligible feature is the moustache as Hellenistic and Roman people were rarely depicted with moustaches. He also has mud-caked hair.

$\mathrm{He}$ is, therefore, a threat to the system of a civilization of which Pergamon considered itself the centre. The only piece of clothing he is wearing is a Toga. This Toga, hanging all the way till his lower back, appears to be waving under the influence of the wind. The fact that he wears it around his neck also means that he is not Greek but Gaul, as Hellenists and Greeks (civilized) mostly worn Togas in different ways. ${ }^{1}$

Next is one of the more important features of the statue: the sword perforating the man's chest; an aim to kill himself. He holds his sword tightly in his right hand with all his arm muscles being in high tension. The sword itself, which is his last chance for survival away from slavery, is short as he must have lost his long sword in battle, and its other features suggest that it is a Roman sword. With his left hand, he is holding the female figure (his wife) on the right of the statue. When we continue down, we arrive at the torso. This torso is also very muscular and again all these muscles are tightened as well, not only because of his suicide attempt, but also because he is holding the woman on the right.

He is standing with his feet apart; his left leg is standing in front of him to support the woman on the right. His right leg is figured backwards for support. Despite the strength and posture of both legs, his muscles are very tense, the feet are beautiful and seem to be almost a live sculpture, but so is the rest of the man. He is depicted with extreme emotion and has received a dignified treatment to evoke a keen sense of sadness or regret, despite the fact that he is a humbled enemy. ${ }^{2}$

Regarding the description of the woman on the right side of the statue, she is being held by the male figure. This woman also has curling hair, but it is a bit longer than that of the man and it implies that probably women fought alongside men. ${ }^{3}$

It also seems like her facial features have ideal proportions. The only difference is that she seems to have a lifeless facial expression. The woman's left-arm is being held by the man. The right arm, like the other, has no muscle tension. Both are hanging towards the ground. The female is wearing clothes to cover her body although she is neither Greek nor Hellenistic (civilized). Her Toga has magnificent elaborated folds. In this situation, her knees appear to rest, and so do her legs and feet; another sign of lifelessness. Like the guy, she is very beautiful and life is properly sculptured. She is portrayed with intense emotion, much like that of the male's, despite the fact that she is also not Greek or Hellenistic, but a Gaul. ${ }^{4}$

When also discussing the ideological worldview centred on the war, the Galatians are depicted as lawless barbarians whereas the conquerors of Asia Minor and Rome as forces of the divine order and civilization. Then, we find the sculptures of the Dying Gaul and the Galatian Suicide memorializing the Galatian myth of the law-defying barbarian "other" of the Galatians, to create the reasons for conquering the Gauls and

\footnotetext{
${ }^{1}$ Spivey, Greek Art, 363-365.

${ }^{2}$ Gates, Ancient Cities: The Archaeology of Urban Life in the Ancient Near East and Egypt, Greece and Rome, 292.

${ }^{3}$ Nieuwkoop, The Galatian Suicide: Unravelling the Ludovisi Gaul killing himself and his wife, 8.

${ }^{4}$ Spivey, Greek Art, 363-365.
} 
the justification for the Roman rule. Therefore, it can be concluded that these statues' subjects portray values, ethics, politics, and intentions. ${ }^{1}$

The two statues' sanctuary was at the Acropolis of Athens, where buildings and statues commemorated the victories of the Attalus (and the Athenians) over the barbarians, i.e. the Dying Gaul and the Galatian Suicide. In this setting, the triumph of the kings was implicitly integrated into the history of military victories by the monuments. Here, the collective memory of the battle against the Gauls met the Greek cultural memory. ${ }^{2}$

\section{The True Motivation for Re-purposing Hellenistic Political Sculptures in the Roman Era:}

We have seen in Pergamon during the Hellenistic period how Atallus I used art and cultural patronage as a way of demonstrating power. This is well-manifested, especially in the Great Altar, Dying Gaul, and Galatian Suicide. The Attalid kings of Pergamon tried to make this Asia Minor city the Athens of the east by uniting cultures via building the Library of Pergamon and unifying worship. The kings encouraged the building of temples for the Athena god and depicted their enemy by likening the Gallic Wars to the Persian ones.

In fact, this victory of Attalus I enhanced the town's reputation concerning the power of culture and politics, and it was commemorated as a great triumph. This group of statues consisting of three bronze life-size figures was set up in front of Pergamon's Acropolis. Two-thirds of this group of statues were created by the Ludovisi Gaul and his wife. The third statue is the Dying Gaul, wherein in this statue it is possible that the man killed his wife in order to prevent her from being captured and raped. These statues reflect the strong connection between culture and the power of politics. These statues were moved to Athens intentionally to show Athens how Pergamon was able to defeat a ruthless enemy that the Athenians themselves failed to conquer. Furthermore, in doing so, Attalus' power and victories over the Gauls were compared to those of Athena's and that they were as a sign of the goddess' support bestowed on Attalid. ${ }^{3}$ It was not just Attalus' victories over the Gauls that attracted attention to the Ludovisi Gaul's history, but they were also compared to Athena as a sign of the goddess's support bestowed on Attalid. ${ }^{4}$ Therefore, it seems that this demonstration of power was used as a propaganda tool for political purposes. In fact, this is not unlike today's political practices as politicians use culture as a topical subject in their speeches and debates to demonstrate their own powers and manipulate public opinion.

The statues offer much more to be seen in them, and it is not only their features and style, but also the fact that they have further become a clear sign for an important political theme related to war. Obviously, this appeared when the Romans had reused classical monuments to provide authority to current monuments, so we find many Greek

\footnotetext{
${ }^{1}$ Darbyshire; Mitchell; Vardar, The Galatian Settlement in Asia Minor, 75-97.

${ }^{2}$ Bagnall Roger and Derow Peter, The Hellenistic Period (United States: John Wiley \& Sons Press, 2004), 155-156.

${ }^{3}$ Tanner, The Invention of Art History in Ancient Greece "Religion, Society and Artistic Rationalisation", 226-227.

${ }^{4}$ Tanner, The Invention of Art History in Ancient Greece "Religion, Society and Artistic Rationalisation", 226-227.
} 
and Hellenistic copies created during the Roman period, especially when Caesar started the Gaul's War and reused the Hellenistic statues of the Gauls. ${ }^{1}$

The Romans were also at odds with the Gauls who lived in Gallia (modern-day France). The Gallic Wars were a series of military campaigns led by Julius Caesar between 58 and $50 \mathrm{BC}$.

Caesar claimed that these wars were a defensive and preventative measure since the Gauls had already caused trouble, but it is also likely that he fought them to boost his political career and pay off his massive debts. This victory empowered Julius Caesar to become the supreme ruler of the Roman Republic after the Battle of Alesia in 52 BC extended the Roman Republic over the Gaul for six years. Caesar himself mentioned these wars in his book: the Commentarii de Bello Gallico.

When Caesar compared his success to the ancient success of Pergamon, which was the centre of the civilised world and had a great reputation in the Roman Republic, the statues acted as propaganda, connecting the victories of the Attalids over the Gauls of Galatia and the victories of the Romans over the Gauls of Gaul. These political and ideological links between Pergamon and Rome are crucial for understanding the Classical tradition of art, as well as the memory of the classic victory over the Gauls from Pergamon to Rome where shared pride caused a migration of statues. ${ }^{2}$

\section{New Artistic Movements Created to Shift the Power Balance and their War Consequences}

Sculptors tended to concentrate on the moment after battles, such as the desperate reactions following the realisation of loss, rather than the turning point of battles or the war violence scenes, which are not common. ${ }^{3}$ All directions lead to the creation of a new scope in Art, such as the one in the Dying Gaul. "The Large Gallic Group" dedicated by Attalus I to the temple of Athena at Pergamon, includes one that depicts a soldier sitting on his fallen shield and turning his eyes to a large mortal wound, ${ }^{4}$ and another one of a Galatian warrior, a nobleman, who kills himself by slicing his throat with his blade, with thick blood streaming out of the wound. ${ }^{5}$

The statue of the Galatian Suicide depicts a Gaul still standing, the sword having opened a deep wound in his throat from which thick blood is dripping. Such a scene would have evoked feelings of joy in the communities of Asia Minor and northern Greece, arising from the joy of survival, but they would also have evoked a sense of respect for heroic death. The inclusion of depictions of Giants and Persians in the "Small Gallic Group" connects Attalid victories to those of the Olympians' over the Giants, and the Greeks' victories over the Persians, turning the then kings of Pergamon into the new guardians of civilization. ${ }^{6}$

\footnotetext{
${ }^{1}$ Spivey, Greek Art, 363-365.

2 Jane Gardner, The Conquest of Gaul, Tarns. Handford (London: Penguin Classics Press, 1983), 16-19.

${ }^{3}$ R. Smith, Hellenistic Sculpture (New York: Thames and Hudson Press, 1991), 99-104.

${ }^{4}$ Ernst; Hans, Die ostgriechischen Grabreliefs, 306-309.

${ }^{5}$ Marina Mattei, Galata Capitolino (Rome: L'Erma di Bretschneider, 1987), 101.

${ }^{6}$ Smith, Hellenistic Sculpture: 102.
} 
When Arts transform from the field of clear representation of battle and soldiers, which is dominated by the works of the field of funerary references to war, we can see a clearer preference for subtle allusions, rather than explicit images of the new revolution in this war. This invokes transient sympathy, especially for women who have died or for other people who have died prematurely, concentrating on the traumatic moment and tragic circumstances of death. Despite their defeat, the enemies' sculpted statues reflect signs of courage and determination, proving that they had not lost the glory of their valour, even after their death.

It was quite common to constantly adapt commemorative anniversaries of wars to new situations and there were occasions when Hellenistic statesmen inspired their people to learn from their past in history. This has indeed occurred when about $220 \mathrm{BC}$, Attalus I founded the Nikephoria, "the festival of Athena Nikephoros who brings victory", in Pergamon to commemorate the Pergamene rulers' victory over the Galatians in Asia Minor ${ }^{1}$ to propagate the idea of the ideology of the victorious king. ${ }^{2}$

\section{How Gaul's Sculptures in Asia Minor (Turkey) are the Main Cause to Create France:}

Despite the Gaulish opposition led by Vercingetorix, the Gauls succumbed to the Roman onslaught by Julius Caesar. The Gauls had some success in Gergovia at first, but were defeated in Alesia in $52 \mathrm{BC}$. The Romans founded towns, such as Lugdunum (Lyon) and Narbonensis (Narbonne) and permitted the life of Cularo to be formalized by correspondence between Lucius Munatius Plancus and Cicero (Grenoble).

Upon his return, Caesar made himself dictator and absolute ruler of Rome and its territories. Julius Caesar split Gaul into several provinces to prevent local identities from being a threat to the Roman influence. Thus, in Gallic (Ancient France), Caesar enacted several reforms, founded many colonies, and provided lands with an opportunity for the poor who chose to migrate to Ancient France. He reduced the number of slaves and opened citizenship up to people living in this area. Under the Roman Empire, there was a clear cultural evolution in Gaul, the most noticeable being the replacement of the Gaulish language with Vulgar Latin. The similarities between the Gaulish and Latin languages favoured the transition. For centuries, Gaul remained under the Roman influence, and the Gallo-Roman culture then gradually replaced the Celtic culture.

Finally, as time elapsed, the Gauls became more integrated within the Empire. Generals Marcus Antonius Primus and Gnaeus Julius Agricola were both born in Gaul, as were emperors Claudius and Caracalla. Emperor Antoninus Pius was also from a Gaulish background.

Consequently, the advent of new artistic movements to commemorate the results of wars had influenced the development of new wars that turned a powerful enemy into a powerful ally, paving the way for the creation of a powerful country like France.

\footnotetext{
1 Jones Christopher, Diodoros Pasparos and the Nicephoria of Pergamon (München: C. H. Beck Press, 1974), 183-205.

2 Austin, The Hellenistic World from Alexander to the Roman Conquest, 197.
} 


\section{Conclusion:}

During the Roman era, Caesar did not want to portray the Gallic as a weakly defeated race, perhaps because they participated in many wars, and they were the reason for his victory in many of them, so he did not want to lose the people's awe of them. Rather, they were depicted in a way that reflects their defeat, but, at the same time, proves their strength, and hence the characteristic structure and design of the Gallic statues. But we cannot deny that this was their reality and not just propaganda.

Evidence provided to prove this is that the origin of these sculptures for the Gallic comes from Attalus during the Hellenistic era; that is before Caesar ever hired them. Perhaps those sculptures created by Attalus; their representations and features, were the basic reason behind motivating Caesar to go to them, dominate them, and then use them to fight in wars next to him to add strength, which in turn has contributed to the emergence of the history of France when Caesar started his reforms there.

Consequently, those sculptures were established as political propaganda for the power of Attalus I, and they were used as propaganda as well for the strength of the Gallic people in war, and they were one of the reasons for Caesar's desire to use the Gauls next to him in battle. Indeed, they helped him in many wars, and as a reward for their military support, Julius Caesar bestowed Roman citizenship upon the people of Arles.

These statues, depicting the Gauls; the opponents, usually portrayed them as no ordinary enemies, but as representatives of a different culture or enemies that threatened the freedom or very existence of a community; as were the Gauls in Asia minor. Hence, victory over them was marked as salvation from a great danger and as the beginning of a new era. ${ }^{1}$

\footnotetext{
${ }^{1}$ Angelos, War in the hellenistic world "A Social and Cultural History”, 228-230.
} 


\section{Catalogue:}

Fig (1) The Acropolis of Pergamon as depicted by Karl Humann in 1881. ${ }^{1}$ plan.

Fig (2) Pergamon Altar of Zeus' is placed in its Architectural sense in this Acropolis

Fig (3) Zeus Altar is now located in Pergamon museum "The Pergamon altar "itself" is now housed in the Pergamon Museum in Berlin". 3

Fig (4) All friezes from the Great Altar at Pergamon Burgberg und Alter Sequence by O. Puchstein and C. Robert. ${ }^{4}$

Fig (5) Comparing between Alkyoneus from Gigantomachy on the Great Altar and Bernard Fischer, "Vatican Laocoön Group". 5

Fig (6) Nike on the frieze of the Great Altar is close in style to the Victory of Samothrace. ${ }^{6}$

Fig (7) Drawing Reconstruction of Pergamene Gallic group monument image from https://www.beazley.ox.ac.uk/sculpture/styles/hellenistic2.htm

Fig (8) Group of Gaul killing himself and his wife, Boncompagni Ludovisi Collection, National Roman Museum, Palazzo Altemps, Rome, Italy. ${ }^{7}$

Fig (9) Dying Gaul. Marble from Dokimeion, Turkey. First century C.E as copy from Hellenistic Era "Roman copy", Musei Capitolini, Rome. (excavated from Vila Ludovisi, Rome) based on original Greek bronze statue of the late third century. ${ }^{8}$

Fig (10) Group of the Galatian Suicide and concentrate on his Bleeding Wound. ${ }^{9}$

\footnotetext{
${ }^{1} \mathrm{http}$ ://digi.ub.uni-heidelberg.de/sammlung16/pergamon1882\&pageid=PAGE0045

2 http://community.middlebury.edu/ slides/HA220/views/aoc046_view.html

${ }^{3}$ https://digi.ub.uni-heidelberg.de/diglit/thiersch1883/0017/image

${ }_{5}^{4} \mathrm{https} / / / \mathrm{www} \cdot$ beazley.ox.ac.uk/Sculpture/ashmolean/context/pergamon.htm

${ }^{5} \mathrm{https} / / / \mathrm{www} . \mathrm{museivaticani.va/content/museivaticani/en/collezioni/musei/museo-pio-clementino/Cortile-}$ Ottagono/laocoonte.html

${ }^{6} \mathrm{http} / / /$ musee.louvre.fr/oal/victoiredesamothrace/victoiredesamothrace_acc_en.html

${ }^{7} \mathrm{http}: / /$ ancientrome.ru/art/artworken/img.htm?id=6621

${ }^{8} \mathrm{https}: / /$ commons.wikimedia.org/wiki/File:Dying_Gaul.jpg

${ }^{9}$ https://digital.library.unt.edu/ark:/67531/metadc43003/
} 
The Gauls Warfare Depiction in Art during the Hellenistic Era

Fig (1)

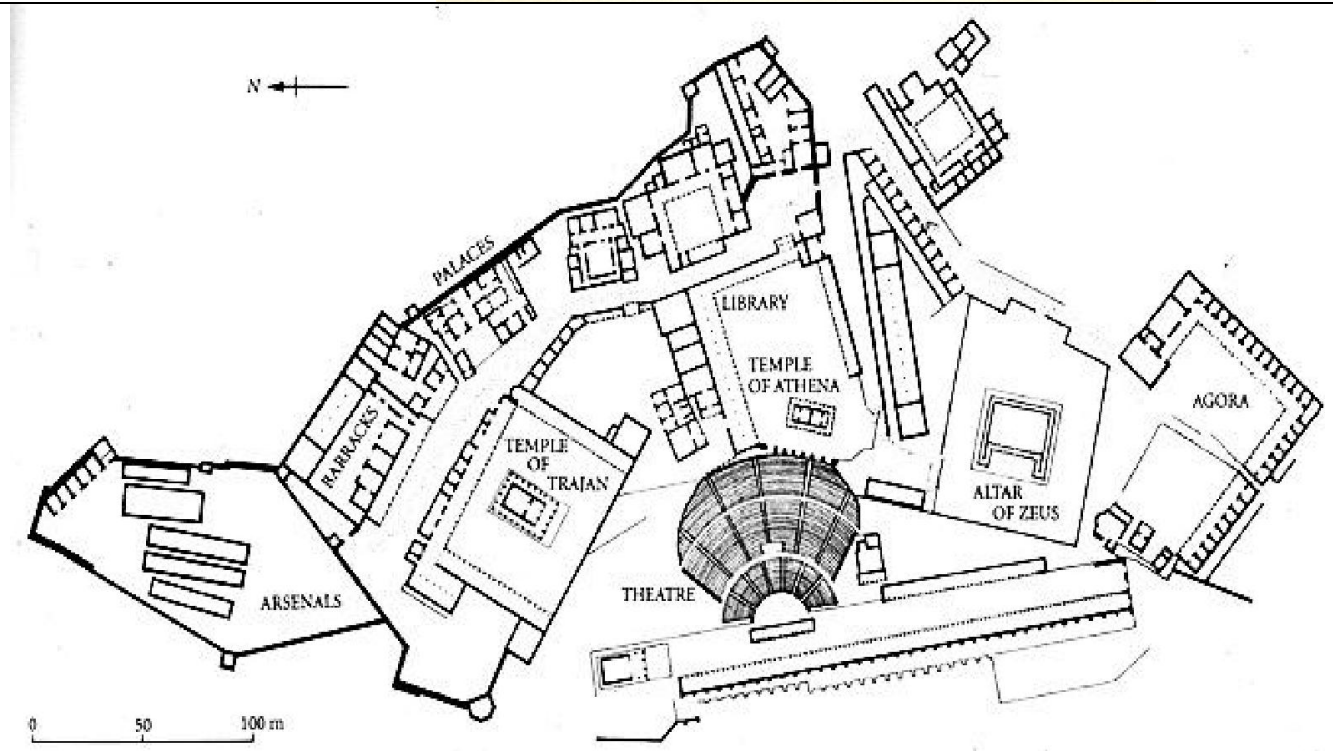

Fig (2) 


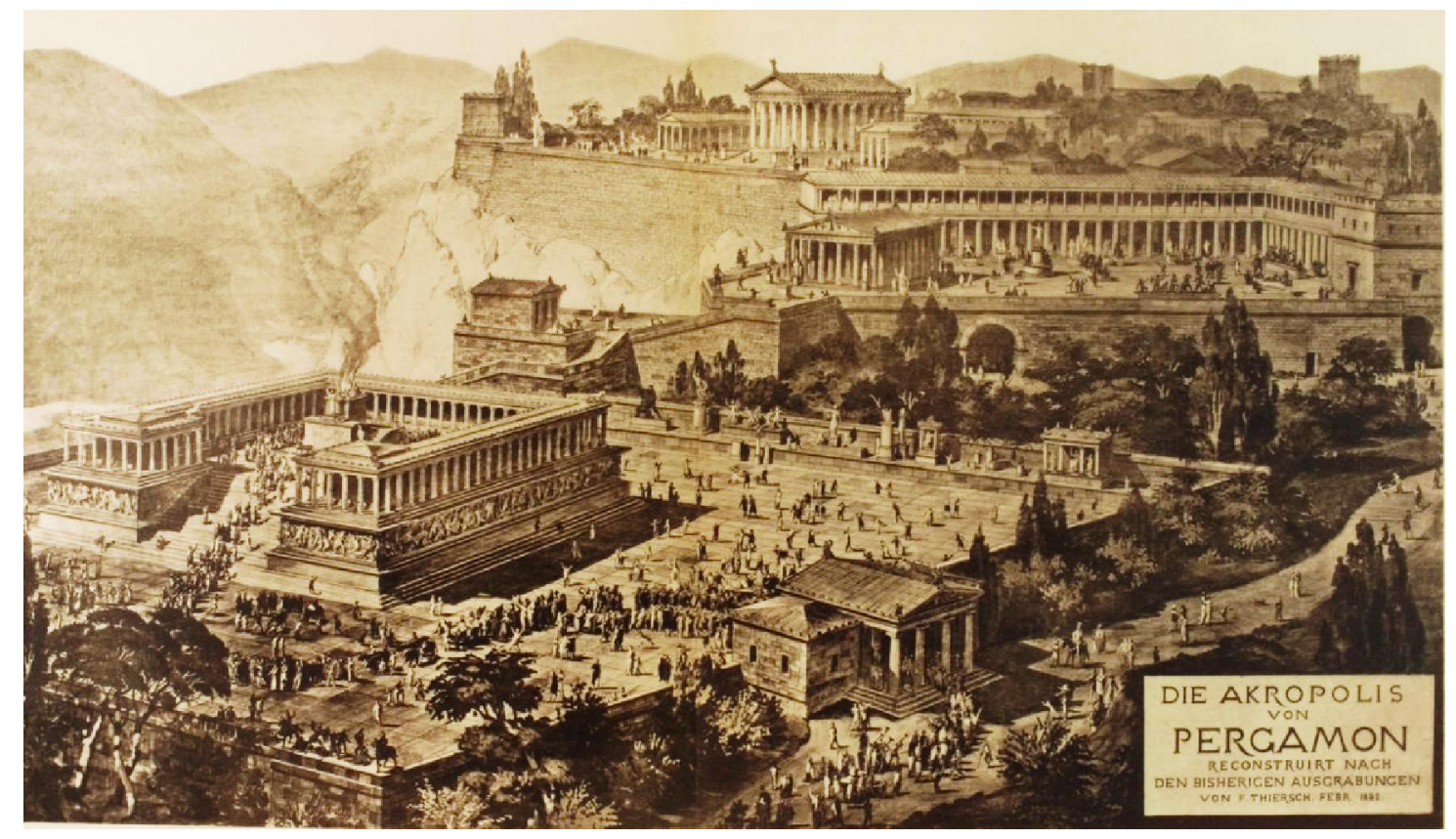

Fig (3)

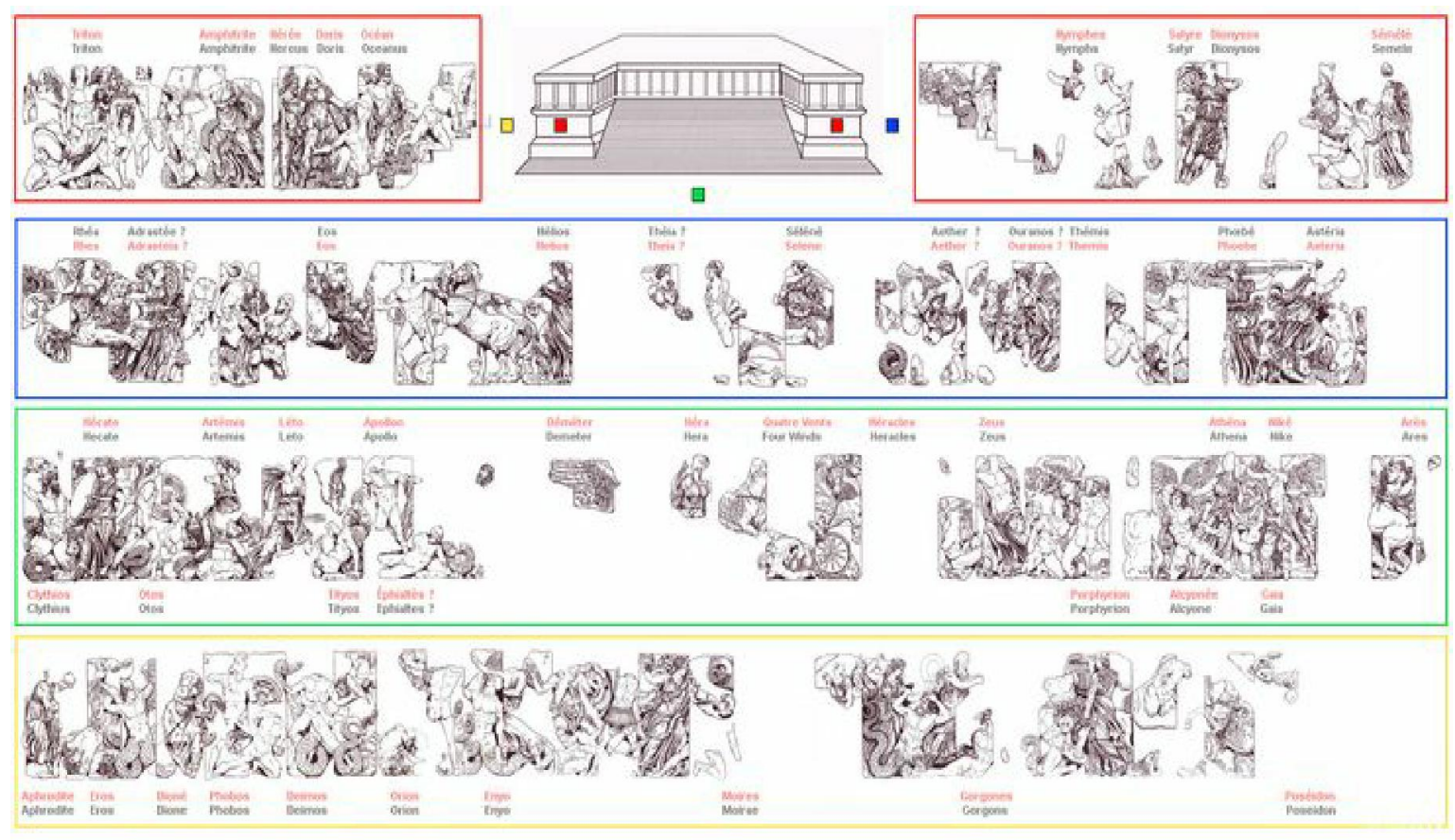

Fig (4) 
The Gauls Warfare Depiction in Art during the Hellenistic Era

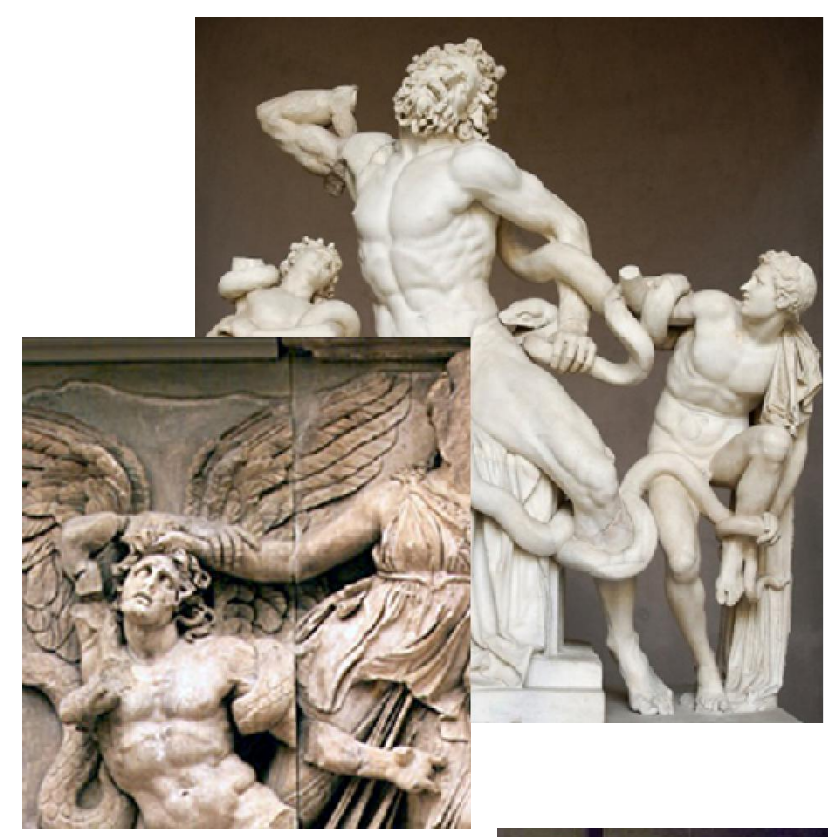

Fig (5)

Fig(6)

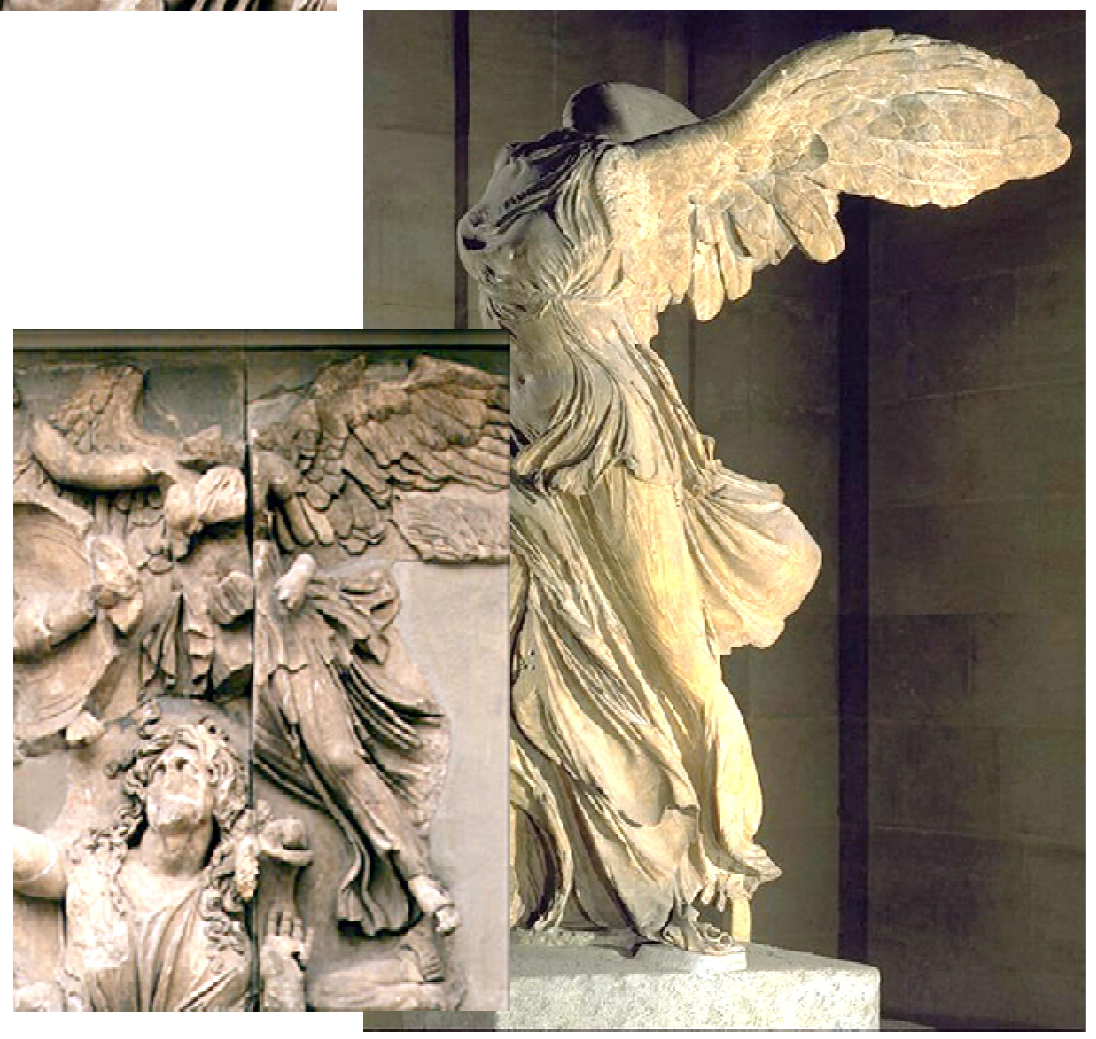




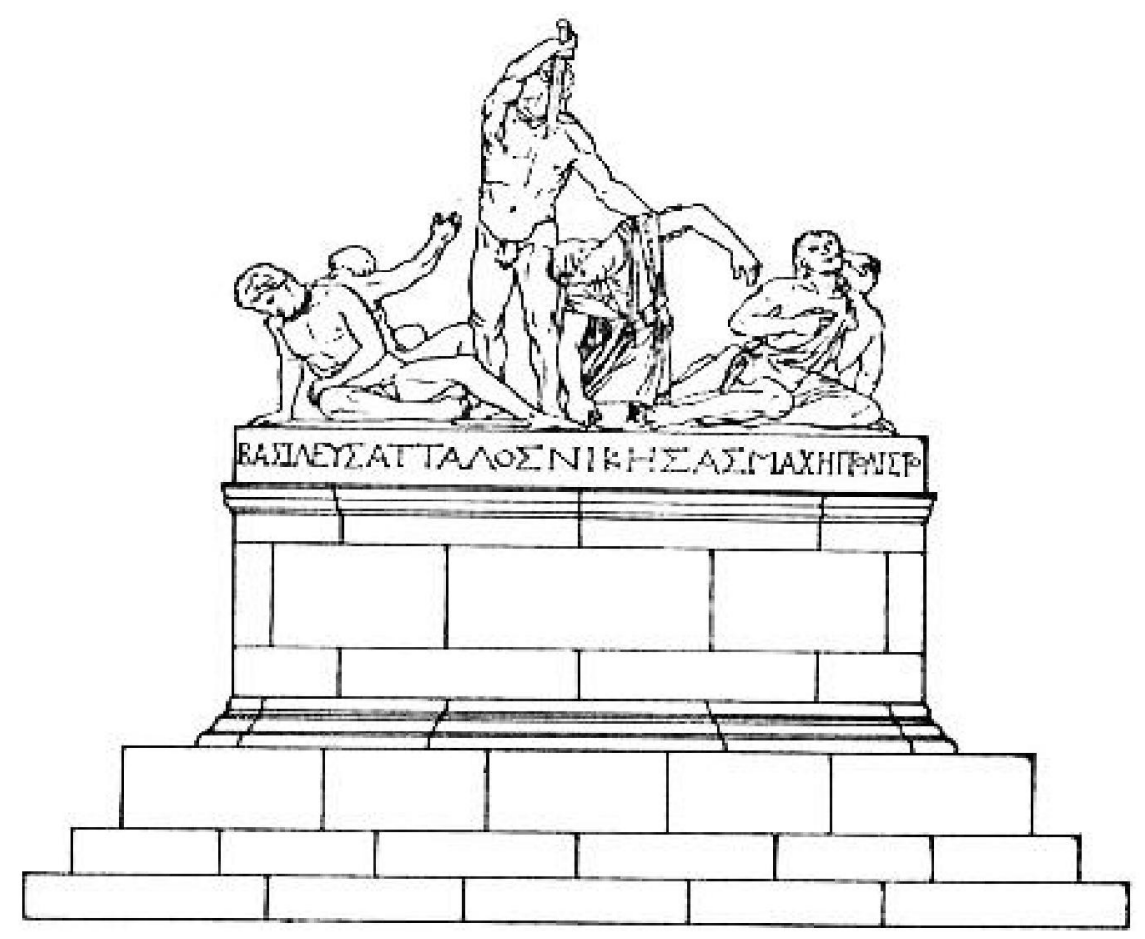

Fig (7)

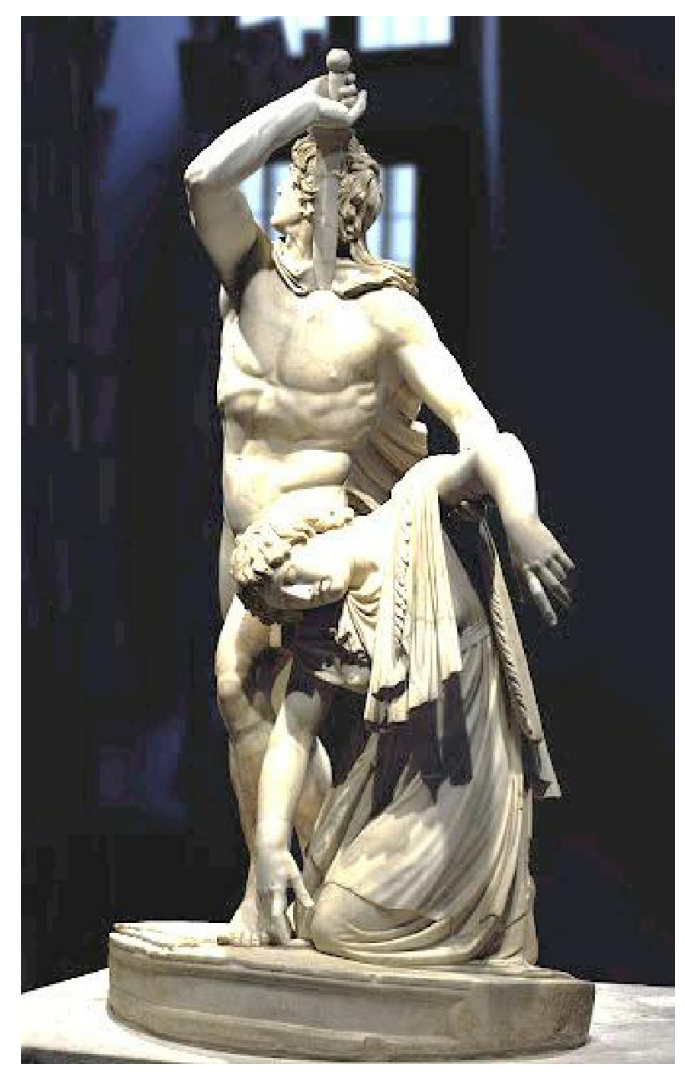

Fig (8) 
The Gauls Warfare Depiction in Art during the Hellenistic Era

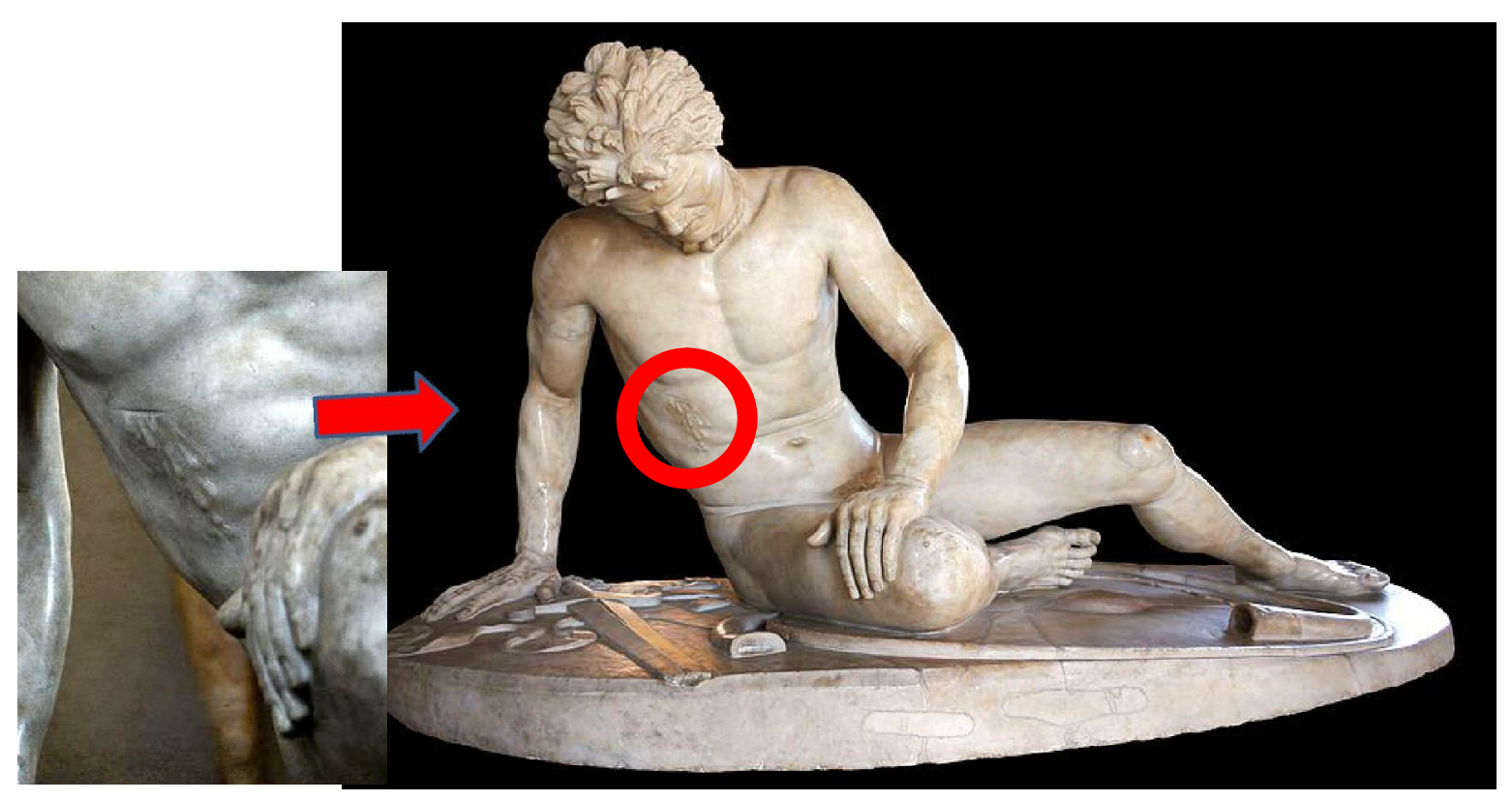

Fig (9)

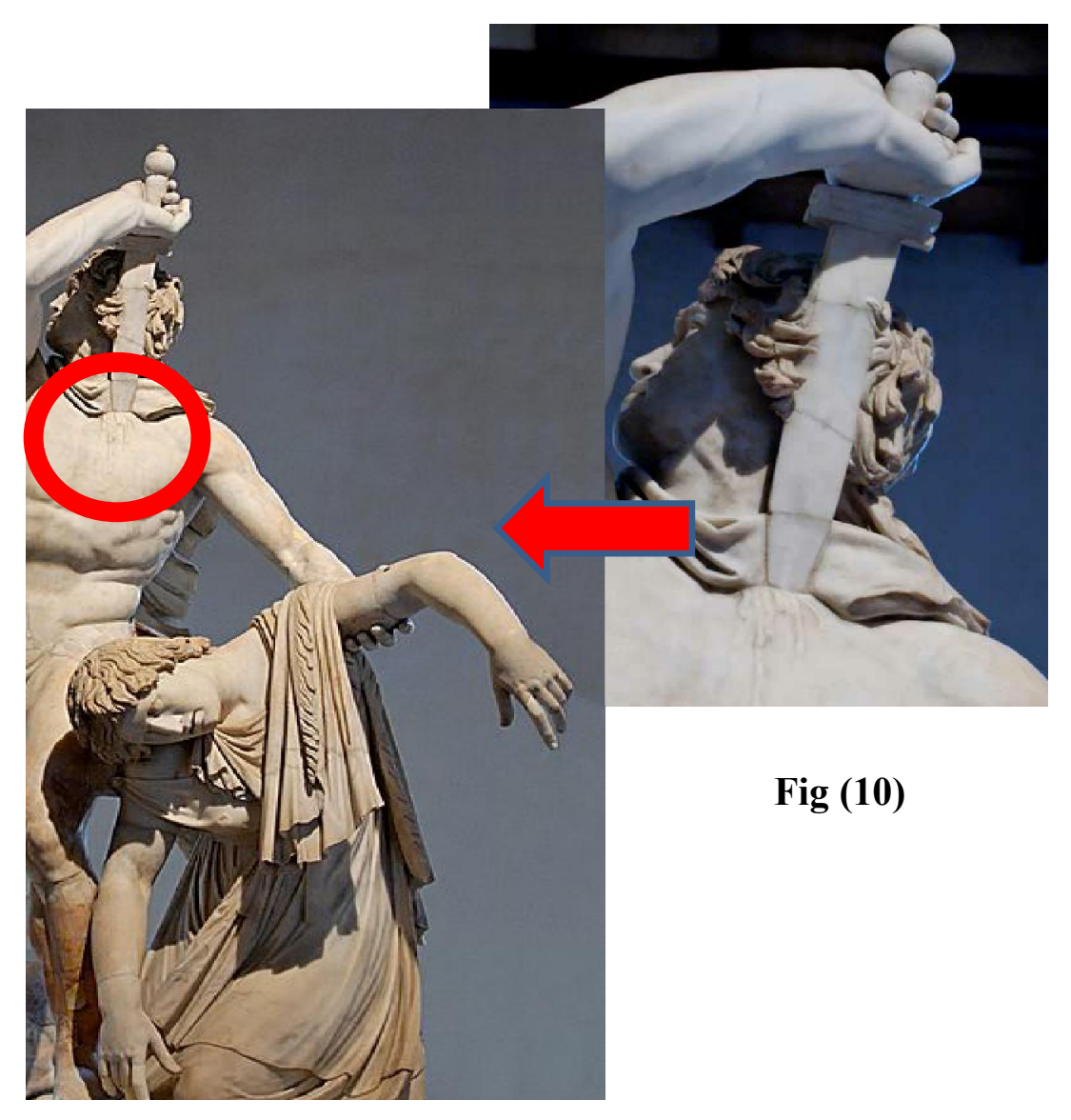




\section{Bibliography}

- Austin, M. M., The Hellenistic World from Alexander to the Roman Conquest: A Selection of Ancient Sources in Translation. Cambridge: 1981.

- Bagnall, R. S., \& Derow, P., Historical Sources in Translation: The Hellenistic Period. Oxford: 2004.

- Boardman, John \& Griffin, Jasper; Murray, Oswyn, The Oxford Illustrated History of Greece and the Hellenistic World. Oxford University Press. 2001.

- Chaniotis, Angelos, War in the hellenistic world "A Social and Cultural History", Blackwill publishing, United kingdom: 2005.

- Churchill,James E., Pergamon and the Great Altar of Zeus: Survey of Western Art I. Lesa Mason press. 2015.

- Cook, B.F., The Elgin Marbles. London: Harvard University Press.1984.

- Darbyshire, Gareth \& Mitchell, Stephen; Vardar, Levent, The Galatian Settlement in Asia Minor. Vol. 50, Published by British Institute at Ankara, jstor Journal Article. 2000.

- Davies, Penelope J.E, \& Denny, Walter B., \& Jacobs, Joseph, Janson's History of Art: the Western tradition. London: Laurence King Publishing, 2016.

- Dreyfus, Renee \& Schraudolph, Ellen, Pergamon: The Telephos Frieze from the Great Altar, vol. I, Fine Arts Museums of San Francisco press, 1996.

- Gardner, P. Jane, The Conquest of Gaul. London: 1983.

- Gates, C., Ancient Cities: The Archaeology of Urban Life in the Ancient Near East and Egypt, Greece, and Rome. London: Routledge, 2003.

- Gosden, Chris \& Marshall, Y., The cultural biography of objects. World Archaeology. 1999.

- Green, Peter, Hellenistic History and Culture. University of California Press, 1993.

- Hansen, E. V., The Attalids of Pergamon. Cornell University Press, Ithaca, 1971.

- Hornblower, Simon \& Spawforth, Antony, The Oxford Companion to Classical Civilization. Oxford University Press, 1998.

- Jones, P. Christopher, Diodoros Pasparos and the Nicephoria of Pergamon. München: C. H. Beck, 1974.

- Kallendorf, Craig W., A Companion to the Classical Tradition. John Wiley \& Sons press, 2008. 
- Kent, Alix, Meetings with the East: Athens and Pergamum. vol 17, PseudoDionysius, 2015.

- Kleiner, Fred S., \& Mamiya, Chrisitin J., Gardener's Art through the Ages. Thomson Wadsworth press, 2005.

- Mattei, Marina, Galata Capitolino. Rome: 1987.

- Nieuwkoop, Marten Van, The Galatian Suicide, Unravelling The Ludovisi Gaul Killing Himself And His Wife. Leiden: Faculty of Archaeoogy Press, 2012.

- Pausanias, Margaret de Gaudrion Merrifield Verrall, Mythology \& Monuments of Ancient Athens: Translation of a Portion of the 'Attica' of Pausanias. Greece: Macmillan press, 1890.

- Pedley, John G., Greek Art and Archaeology. Prentice Hall Press, 2012.

- Perry, Walter Copland, Greek and Roman Sculpture: A Popular Introduction to the History of Greek and Roman Sculpture. Longmans press, 1882.

- Pfuhl, Ernst \& Möbius, Hans, Die ostgriechischen Grabreliefs. Mainz: 1979.

- Pollitt, Jerome, Art in the Hellenistic Age. Cambridge University press. 1986.

- Portnova, Tatiana, Giants against God's, European Research Studies. Volume XVIII, Issue 4, Special Issue, 2015.

- Ridgway, Brunilde Sismondo, Hellenistic Sculpture. Volume 1, University of Wisconsin Press, 1990.

- Russel, J. Barrnett, “The Pergamon Altar”. Publishing house, 2012.

- Shanks, Michael \& Tilley, Christopher, Social theory and Archaeology. Cambridge: Oily press, 1987.

- Smith, R. R. R., Hellenistic Sculpture: A Handbook, New York: 1991.

- Spivey, N., Greek Art. London: Phaidon Press, 1997.

- Stewart, Andrew F., \& Korres, Manolēs, Attalos, Athens, and the Akropolis: the Pergamene 'Little Barbarians' and their Roman and Renaissance legacy. Cambridge University Press, 2004.

- Tanner, J., The Invention of Art History in Ancient Greece: Religion, Society and Artistic Rationalisation. Cambridge University Press, 2006.

- Wade, Herbert Treadwell, The New International Encyclopaedia. Mead and company Press, 1930.

- weiss, Peter \& Neugroschel, Joachim, A Visit to the Pergamon Altar. Berlin: 1999. 
The Gauls Warfare Depiction in Art during the Hellenistic Era

\section{Website Bibliography}

- http://digi.ub.uniheidelberg.de/sammlung16/pergamon1882\&pageid=PAGE0045

- http://community.middlebury.edu/ slides/HA220/views/aoc046_view.html

- https://digi.ub.uni-heidelberg.de/diglit/thiersch1883/0017/image

- https://www.beazley.ox.ac.uk/Sculpture/ashmolean/context/pergamon.htm

- https://www.museivaticani.va/content/museivaticani/en/collezioni/musei/museopio-clementino/Cortile-Ottagono/laocoonte.html

- http://musee.louvre.fr/oal/victoiredesamothrace/victoiredesamothrace acc en.ht $\underline{\mathrm{ml}}$

- http://ancientrome.ru/art/artworken/img.htm?id=6621

- https://commons.wikimedia.org/wiki/File:Dying_Gaul.jpg

- https://digital.library.unt.edu/ark:/67531/metadc43003/ 